\title{
"Education Ltd."-The Influence of British Earl of Cromer on the Education System in Egypt (1883-1907)
}

\author{
Yossi Maman ${ }^{1,2}$, Janan Faraj Falah1 \\ ${ }^{1}$ The Arab College for Education, Haifa, Israel \\ ${ }^{2}$ Ohalo College, Katzreen, Israel \\ Email: docmaman@gmail.com, jananf81@gmail.com
}

How to cite this paper: Maman, Y., \& Falah, J. F. (2018). "Education Ltd."-The Influence of British Earl of Cromer on the Education System in Egypt (1883-1907). Advances in Historical Studies, 7, 79-96. https://doi.org/10.4236/ahs.2018.72006

Received: February 2, 2018

Accepted: June 11, 2018

Published: June 14, 2018

Copyright (c) 2018 by authors and Scientific Research Publishing Inc. This work is licensed under the Creative Commons Attribution International License (CC BY 4.0).

http://creativecommons.org/licenses/by/4.0/ (c) (i) Open Access

\begin{abstract}
This research focuses on a historic issue: the influence of the Earl of Cromer (who served as the British Consul-General in Egypt) on the local education system. The research reflects an inter-disciplinary approach-education and history. Coping with the issue was done via examination of the declared educational goals and the activities in practice as well as the local population's responses to the activities. Allegedly, Cromer failed in his attempted reforms in Egyptian education. This article attempts to examine the issue from a process-holistic approach attributing meaning to all actions taken by Cromer in the education system. The major leading goal of this research is the examination of the education system in Egypt during the British occupation, when the Earl of Cromer served as the British Consul-General from September 11, 1883 to the end of his term on May 6, 1907. Cromer is claimed to have ailed his reforms in Egyptian education, and so this article will attempt to separate the educational goals set by the British and Cromer and the actual practice in the field. We will also relate to the local population's responses to these activities.
\end{abstract}

\section{Keywords}

History, Education, British Council, Egypt

\section{Introduction}

In this article, the intention is to identify and examine the events, activities and thinking patterns of those involved, and present varied information and criticism, and to deal with the following questions: Did the British make efforts to introduce changes in the benefit of education in Egypt? What was done in the 
domain of intellectual progress? Did they only encourage the acquisition of "limited knowledge" due to their view of maintaining Egypt at a state of intellectual degeneration? Or did they adopt a genuine educational policy? Did they make efforts to educate the Egyptians and to lead them to a state of self-rule?

The findings are mostly based on readings in primary sources-books written about Egypt, about the British in Egypt and about the Earl of Cromer as well as the latter's own writings (see references in the end). The collection of information was done inductively (from the individual to the general), and so, in the process of reading, any piece of information pertaining to Cromer of the British in Egypt, especially information about education was copied, including a specific reference (book, page). In the second stage, based on all the information that had been collected, categories were constructed on the logical continuum. The following are the various chapters: historical-educational background prior to Cromer's consulship in Egypt-Britain's goals and Cromer's goals in the domain of education ("declarative level"); activities in the field of education (appointments, budgets and tuition, examinations, language of teaching, primary and secondary education, teacher education, women's education, higher education institutions); difficulties on the way to achieve changes in the education filed and the local population's responses to the educational activities. Finally, the main question is-did the Earl of Cromer fail, or did he succeed in promoting the Education system in Egypt?

\section{Historical Background}

It is important to note two main periods of great significance in the Egyptian education system in the time preceding the British regime. The first is during the regime of Muhammad Ali Pasha (1805-1849), who built a national education system which sought to provide highly skilled personnel to national services, the army in particular. The system consisted of primary and secondary schools, and national technical schools in addition to high education institutions such as the medical school opened in 1827 by the French Claude Bey. Furthermore, groups of young Egyptians were sent to study in Europe (Cameron, 1898; Milner, 1904).

Additional activities included setting up a curriculum committee for all schools in 1822, and a languages school in 1835 (Vatikiotis, 1983: p. 94).

I will note that at that time the education system was supervised by the Al-Azhar institution and included schools which were adjacent to the mosques.

The second period was in the years 1863-1879 when Ismail, son of Ibrahim Pasha and grandson of Muhammad Ali Pasha governed the land. Ismail wanted to encourage the field of education and hence, he established the school council which later became the Ministry of Education, and appointed vigorous, dedicated people such as Ibrahim and Ali Pasha. He also founded professional law, administration, engineering, language and technical schools and appointed Swiss DorBey in charge of their improvement and expansion (Vatikiotis, 1983).

He even donated his own money to schools, and in 1872 he inaugurated a 
teacher education school for the training of Arabic teachers, and in 1873, the first girls' school was established, where the curriculum included calculus, geography, history, religious studies together with practical home chores training such as sewing and weaving, In 1875 he established the Geographical society and the National Library and donated to professional medical and educational periodicals (Young, 1927; Vatikiotis, 1983).

Still, there was a decline in education during his reign compared to the times of Muhammad Ali, which was expressed in a decrease in the number of educational institutions as a result of national financial pressures. Many high schools were 9 joined together, some closed down and the number of pupils in the system decreased (Tignor, 1966).

What, then, was the nature of the education system upon British conquest? What was the role of religious institutions?

In fact, there were two main educational streams: Islamic education, which was based on religious schools "Khutab", which were adjacent to the mosques in the villages and cities and supervised by "Al-Azhar"; the second was that of national education including primary and secondary schools developed by Ismail based on the French model. Additionally, there were high education institutions such as a medical school, a school of languages and a law school. An additional education system included "foreign schools" managed by missionaries who provided primary and secondary education and whose curriculum was not under any supervision (Marlowe, 1965).

Religious education was governed by the "Al-Azhar" institution which was the most important for Moslems, as there lay the roots of the educational perception which shaped the teachers. The latter studied and had to pass tests in order to examine their knowledge of the Quran, tradition and Islamic law. One of the requirements was reciting from the Quran (Newman, 1928).

The students learnt reading and writing classical Arabic and memorized long parts of the Quran and its interpretations; they learnt about the life of Muhammad and received explanations about religious texts. Learning was done in small groups, whereby students were exposed to religious debates. Calculus and astronomy were secondary subject (Sladen, 1908; Low, 1914).

Local learning options were in the Khutab, adjacent to the mosques in the rural and urban areas. The goal was to teach reading and writing and to impart religious knowledge via the Quran. Teachers were trained in "Al-Azhar" and first taught the alphabet on a small board on which they wrote. The students then got to learn the numerical value of each letter and finally learnt to write the 99 names of God and a few other difficult words. Once they mastered the spelling of the words, they progressed towards the first Quran chapter, and then studied the last chapter. Thus, gradually, they read the entire Quran in Arabic, which was considered a religious duty. Only then did they start learning the grammar. The pupils would sit on the ground, moving their bodies back and forward. They wrote their lessons on wooden boards. When the lesson was over, the board was erased, and a new lesson was written on it. A copy of the Quran was placed on a 
small table made of palm branches (Lane, 1908; Tignor, 1966; Cromer, 1908b).

National education was primarily based on a system which was developed by Ismail, where teachers from Europe or local teachers who specialized in western teaching practices taught. The most common type of learning was via exercising memory rather than by developing thinking. The emphasis was on learning texts and formulae (Milner, 1904).

In December 1875, the British government sent a delegation to Egypt, headed by Stephen Kibbe, in the attempt to investigate the situation in Egypt. The report published that year concluded that "Egypt suffered from ignorance" (Newman, 1928).

\section{Goals of Education}

\subsection{Britain's Goals}

To examine the goals of Britain in the domain of education in Egypt, we must first review Britain's approach to occupation of Egypt. Lord Lloyd states Britain had always sought to act in the benefit of the local population by implementing necessary reforms. At the same time, Britain intended to improve the field of Egyptian administration, cure it from its corruption so goal could be achieved in the future via self-management (Lloyd, 1933; Vatikiotis, 1983). The British were also inclined, in their view of their occupation of the east as a mission to establish justice, to help those who were struggling for the right to progress and take the locals "from the world of darkness to a world of light" (Colvin, 1906; Blunt, 1895).

Which expectations did the British have regarding the education system and what were their goals? Many leading British politicians and influential newspapers never got titred of requesting that Egyptian education be developed fast, as a measure of a local autonomous growth, the emphasis being on implementing an educational reform so as to prepare the Egyptians to the time when they will manage their state on their own (Cromer, 1915; Tignor, 1966). The idea was that schools under British supervision would provide the learners with genuine educational values, which would lead to improving the personal traits and intelligence of the administration class, and from there, appointing stake holders who had passed the exams and acquired knowledge for a purpose other than gaining personal benefits (Lloyd, 1933; Milner, 1904).

The proper primary education development would be made possible via integrating the existing religious studies with general studies which would educate the learners and provide them with the necessary knowledge for coping with the different life situations they may encounter outside the school. First secular education would be addressed, whereby the reform will start and reach a level where it will compete with religious education, and indirectly cause an improvement in the religious institutions' teaching methods (Lloyd, 1933). Those operating in the educational frameworks must remember that there are wrongdoings in schools, and those have to be fought against. Instead of feeding mem- 
ory, thinking has to be encouraged, and emphasis has to be placed on quality rather than quantity. Furthermore, the pupils would have to demonstrate their skills by passing exams in order to pass to a higher school, and attention would be paid to discipline, behavior and physical fitness (Milner, 1904).

\subsection{Lord Cromer's Declared Goals}

Cromer regarded education as a means for achieving various goals such as training public officials and guaranteeing effective civil services by way of improving the western system in the schools and training the youngsters enrolled in the schools towards employment in government services. At the same time he intended to train teachers by opening special teacher education schools, thus improving education for women (Marlowe, 1970; Tignor, 1966).

An additional goal was raising the level of the population via focusing on extending primary education via the government "Khutabs" which were directly governed by the department of education of each village, and city neighborhoods. In this way primary education would be provided to a large number of residents, and the poor would also be entitled to basic education, which will be of moral and intellectual value in the future (Lloyd, 1933; Tignor, 1966; Colvin, 1906; Marlowe, 1970).

Cromer also emphasized encouraging and expanding technological education, due to the need to provide western technological knowledge, allowing those who have technical skills options for learning a trade and produce as many "carpenters, builders and plasterers” (Mansfield, 1971; Cromer, 1908b; Tignor, 1966). Cromer offered to improve high education in the state regarding medical studies. According to him the best way to satisfy Egypt's medical needs without flooding the country with doctors, would be to take the issue of training doctors and their education very seriously (Cromer, 1908b).

Cromer regarded his role as highly important, and said the British did not arrive in Egypt as conquerors, but as saviors of their society, and as such they had to believe in their goals and be convinced the mission was indeed to save Egyptian society, and so he believed the British did not only have to tell, but also to remain in Egypt and act (Cromer, 1908b). He stated one of the reasons for his belief in British involvement in Egypt is the ignorance of the population, and hence it was important to heal those wounds in the Egyptian character by providing personal examples and reaching a high level of morality in both personal and public life (Cromer, 1908b; Marlowe, 1970).

\subsection{Lord Cromer's Undeclared Goals}

Were there other educational goals which Cromer did not declare overtly? One of Cromer's primary concerns was to limit the number of primary and secondary school graduates to a number that could integrate into government administration positions. He strove to keep the Egyptians at a certain knowledge level that would correspond to the dismissal of Egyptian officials and creating a lack of suitable managers, so he would have just cause in filling the positions with 
British officials (Al Sayyid, 1968; Mansfield, 1971).

Cromer's critics argue he did not wish to raise the level of education so as not to create an unhappy class of intellectuals. Since he totally negated nationwide expansion of secondary and high education, as he thought it would generate subversive demagogues, he was reluctant to establish an Egyptian university, fearing it would be a source of discontent on the part of Egyptian nationalists.

Externally, his explanations were that an intellectual will be detached from the Egyptian population within which one lives, and despite what the British do, education must progress naturally and produce natural results. One of these natural results may be the wish to get rid of the foreigners (Tignor, 1966; Mansfield, 1971).

Part of his policy was based on the premise that Britain had to remain in Egypt so as to prevent others from establishing their domination there. "Others" were the French, who despite British occupation, influenced the different areas of life, and whose influence was considerable on the educated Egyptians.

In high education institutions, French was a popular language, for instance in the College of Law, which attracted the talented high school graduates. Teaching in French was conducted by most teachers who were originally French. Cromer had a clear intention to compete against the French language at the first stage and later replace it with English (Cromer, 1908a; Mansfield, 1971; Tignor, 1966; Lloyd, 1933). Furthermore, Cromer sought to awaken a sense of loyalty to the British Empire by convincing the new Egyptian generation to accept the spirit of western culture and be aware of its being genuine (Mansfield, 1971; Cromer, 1908b; Lloyd, 1933).

\section{Education Related Activities}

\subsection{Appointments}

The department of education turned into a department in the Ministry of Internal Affairs, and Cromer appointed delegates whose job was to travel along the land in villages and cities so as to assess the state of education and collect information about the residents' wish to learn. The results testified to the residents wish to learn and expected the Government to build schools in the villages (Newman, 1928; Cromer, 1908b). In 1890 he enlisted Douglas Dunlop as a chief consultant, and Dunlop set uniform working regulations in the department and demanded the workers' full obedience. After a short while he gained a position of power and at the same time he mobilized graduates of high education institutions in Britain to the department, while approaching directors of Egyptian institutions not to accept candidates who passed tests in Arabic, as teachers in Egypt, as it would give them different ideas about the locals, they would waste their time and not teach English (Mansfield, 1971; Cromer, 1908b; Al Sayyid, 1968). Furthermore, British teachers who got jobs in Egypt and wished to remain there were promoted to high positions in government offices. Additionally, the department head had the authority to establish new schools, terminate the 
activities of others, determine schedules and teaching methods and demand emphasis on educational principles according to need. The schools supervised by Dunlop were managed in full coordination with him (Newman, 1928; Milner, 1904).

In 1906, Cromer raised the department of education to a Ministry level, and appointed Saad Zaghloul as its head. Zaghloul was an honest, moderate person and there are different opinions regarding his appointment. One was that it was the decision of the new Liberal British government in London, wishing to allow a further step in the development of independent Egyptian government, and to create Egyptian involvement, and not due to dissatisfaction with the ministry's work or due to their will to introduce radical changes in work procedures and educational policy (Alexander, 1911; Lloyd, 1933).

The second, Cromer's calculated initiative seeking to calm the anger of nationalist groups, and at the same time encourage the moderate forces in Egypt (Kadouri, 1969).

\subsection{Budgets and Tuition}

The annual education budget revolved around 70 thousand Pounds Sterling a year, and was doubly validated in the resolution of a conference held in London in 1885, setting the budget as a permanent one (Tignor, 1966; Cromer, 1908b). In 1890 the finance department increased the amount spent on education to 81 thousand Pounds Sterling, and in 1906, the same amount was spent, which did not exceed 1.5\% of the government expenditure (Little, 1971; Cromer, 1908b).

Some claim education budgets were only obtained after funding was allocated for the Ministry of Agriculture, and when the Ministry of Education required funds for a specific project, that cost 5000 pounds, they would encounter difficulties, and explanation the project costs Britain 10,000 pounds (Tignor, 1966; Milner, 1904). Cromer abolished free primary education and argued the best way to find if Egyptians really want to be educated is to ask them whether they are willing to pay for education (Cromer, 1908b). Tingor claimed parents had to pay the school due to pressures on the British government and its wish to narrow the budget to the necessary minimum, and Cromer used the money to develop other aspects of the education system such as technical schools, rural schools and teacher education programs. Tingor criticizes Cromer by stating Cromer believed education was not the most important for the British government, and though he was willing to contribute to technical schools, he obligated students in high education institutes to pay tuition. Tingor also criticized the fact the British government regarded the intellectual life of a state as a private rather than government issue, and the belief the Egyptians would appreciate education was by paying for it (Tignor, 1966).

\subsection{Examinations}

Cromer's policy in this domain was decisive. He introduced the practice of examinations in primary schools, I teacher education programs and in higher 
education. The examinations required the examinees to reach a specific level, and were hard enough to make sure some would fail. Examinations were conducted in the same language used for teaching (Tignorp, 1966; Mansfield, 1971). The goal was to accept to high school pupils who passed the primary school's graduation examinations. The same policy applied to all the institutions of the education system. Indeed, between the years 1887-1892, examinations were held on the primary and high school levels and those who passed received certificates (Elgood, 1928; Tignor, 1966).

Dunlop even sought to impose discipline and introduce principles and methods whose goal was to prevent pupils from bribing or cheating to succeed (Mansfield, 1971). Nevertheless, Milner claims there was no adherence to the principle of entering the civil service after passing the examinations, and that the examinations were redundant for two reasons: the examining body was not updated regarding its work, and additionally, there were not enough locals who could meet the examinations' high demands (Milner, 1904).

\subsection{Languages}

In the early days of occupation, the British showed contempt to the Arabic language, and there are those who quoted education department officials saying they do not want to hear about and English person knowing or speaking Arabic. They did not regard Arabic as a scientific language, but rather as an inaccurate language lacking vocabulary. Hence the teaching of science and other subjects was conducted in English (Tignor, 1966). English lessons were introduced to the national education system, and English soon replaced the French language as an additional language taught in school. Between 1889 and 1998, the number of pupils who learnt English increased from 1063 to 3859 whereas the number of pupils who learnt French decreased from 2994 to 1881. Mansfield maintains this was largely due to material goals-knowledge of the language in government service, to which most students aspired, as English became the governing language in the bureaucratic system (Mansfield, 1971). Furthermore, the British were of the opinion that the pupils would learn one language in depth, instead of learning a number of languages, and so they would gain practical knowledge with a modern, scientific language and translate their thoughts anew, thus achieving the goal of getting the true meaning of learning history, geography and other subjects which cannot be learnt in Arabic (Milner, 1904).

Nevertheless, before the end of Cromer's office, Arabic started seeping into primary schools more significantly than to high schools. Cromer confirmed that in time Arabic would become the formal language in school again. That happened because learning English was proven as hard and ineffective due to increased pressure from Egyptians nationalists. Dunlop also advised British teachers to learn Arabic in their free time. It is interesting that despite all efforts, French remained popular within the Egyptian population in general and in cultural life in particular despite the British attempts to minimize its significance (Mansfield, 1971). 


\subsection{Primary and Secondary Education}

Cromer's policy sought to focus on primary education. Accommodations were made to pupils and efforts were made to provide them with basic education in language, calculus, geography, reading and writing, and whereas budget allocations were available, attempts were made to improve the "Khutabs" which were directly managed by the government (Mansfield, 1971; Tignor, 1966). "Indeed the number of government supervised primary schools in 1906 was 4554, and they included 165,000 pupils. There were 505 secondary schools. There were higher education institutions with some 100,000 students. A survey showed that $11 \%$ of the males aged seven and above could read and write (Newman, 1928; Tignor, 1966; Cromer, 1908b).

\subsection{Teacher Education and Women's Education}

Cromer did not take serious and comprehensive action to promote the education of women in Egypt, and his attitude to the issue was ambiguous. The British believed that the increase in education among Egyptian girls in 1899 "created a new class of servants" (Mansfield, 1971). Although the British claimed the possibilities of women's education increased and that girls were interested in learning teaching and nursing, in practice, only 20,000 girls constituting $1 \%$ of school-age girls were enrolled in state supervised institutions (Mansfield, 1971; Cromer, 1908b; Colvin, 1906).

Egyptian teachers studied in a teacher education college which operated with government help funds. The students found themselves between traditional education and the European methods, between the main aspects of tradition and the institution's goals-instilling in them the foundations and spirit of modern knowledge and teaching them how to teach. A few college graduates were accepted to work, and most of them were too young (Tignor, 1966; Milner, 1904). Mansfied claims nothing was done to raise the level of teachers and improve teaching methods, which were educationally worthless. He adds that Cromer did nothing to increase the number of teachers. There was no teacher education institution which trained teacher for secondary education, and the teacher education college that did operate was at a low level, and its students were either too poor or not educated enough to study elsewhere. He states that a number of teachers, who were sent to specialize abroad, were then hired by Dunlop for management work in the department of education upon their return to Egypt. All that despite the fact that Cromer had confirmed they wanted to teach, due to the fact that young Egyptian men started looking for more educated wives, but he saw no British duty to grant their wish (Wallace, 1883; Marlowe, 1970).

\subsection{Higher Education Institutions}

The Law School was managed by Lambert, a French professor, and teaching was mostly conducted in French, and so it was hard to introduce English into that institution. Lambert blamed the British for unjust intervention in the school. His 
accusations were published in the local press. He mostly blamed Dunlop for making it hard for the French teachers and encouraging students to move to the English sector. The pressure for creating an English sector caused bitterness and tension between the English and the French staffs, and eventually, this tension led to Dunlop's replacing Lambert in 1907 with the British historian, hill, who was then granted his Masters degree in Paris, claiming he was the first to sign a petition for releasing prisoners (Mansfield, 1971; Tignor, 1966; Alexander, 1911; Colvin, 1906).

In 1890, the British managed to gain control of the School of Medicine. At first they tried to underrate it so as to decrease the number of graduates, and hence they launched a campaign whereby they wanted to show the school lacked psychiatric and pathological literature and that it did not provide adequate education and tools for doctors and hence its graduates are ignorant in medicine. Later, the teaching language was changed into English, and British teachers and inspectors were appointed. The intention was to take the school to the highest possible level, and it is clear this would be achieved if doctors from Britain influenced the school and the contents taught, including expansion of teaching western knowledge. Indeed the British influence was expressed in the involvement of British clinical experts. In 1897 an expert was sent from a London hospital to make recommendations for the school's reorganization, and as a result of his recommendations, the number of study years decreased from six to two years and graduates were sent to an internship period in Britain after passing the medical school's difficult final examinations (Tignor, 1966; Mansfield, 1971; Cromer, 1908b).

\section{Obstacles on the Way to Reform}

During Lord Cromer's stay in Egypt, and even after his departure, he never felt that the real problems in Egypt were not due to voting on reforms or methods to be used, but also due to the circumstances whereby the reforms had to be implemented, and which reforms were too complicated to implement (Al Sayyid, 1968; Cromer, 1908b).

One of the main obstacles to the implementation of new educational programs was lack of budgets to the Ministry of Education, going back to Egypt's economic problems in the beginning of British occupation, when the race to overcome bankruptcy was at its peak, and there was a need to economize. Even after overcoming the economic distress in 1904, there was a feeling that although it is necessary to provide education to children in the state, it was more important to limit the excessive tax demanded from parents, and financial welfare outweighed anything else (Milner, 1904; Lloyd, 1933; Cromer, 1908b).

Another obstacle was that of the Pasha establishment. It is not true the Pashas did not wish to advance education in Egypt. Many of them aspired to achieve such advancements, because they realized that acquiring knowledge was the only way Egypt could free itself from foreign occupation. However, the Pashas them- 
selves were not educated enough to initiate the steps that would satisfy their legitimate ambitions. Implementation of their policy led to conclusions which their prejudice caused them to reject, and the natural result was the Pashas policy was unstable and its influences were enhanced by appointing relatives to different positions during British occupation. In his early days of office, Cromer noted that between 1863 and 1892, the Minister of Public Instruction had been replaced 29 times, and that each such change caused havoc, as every new appointment meant changing its predecessor's style. Those frequent changes constituted setbacks in the application of educational programs which had already been under way, and Cromer had no doubt that if he had a say in it, things would have moved a good deal faster (Cromer, 1908b; Newman, 1928).

The Egyptian population was faithful to the Islamic tradition, and Cromer's attitude to Islam was far from positive, and he refused to believe Islam allow secular reforms and thus change. He believed the main goal of Islam was to gain knowledge about Muhammad's religion, and anything beyond that was considered unnecessary, even dangerous. Islam with reforms is not Islam, and there is no doubt that in primitive societies, one could enjoy the benefit of doubt by choosing to believe in Islam (Mansfield, 1971; Al Sayyid, 1968; Cromer, 1908b).

Under these circumstances, it was clear that institutions like "Al-Azhar", on their lack of imagination and openness, constituted barriers to any development in the educational domain, and that education could not be used for raising the general educational level in Egypt. Therefore, Cromer made no use of Al-Azhar, also for reasons of fear it could be a source of Anti-British propaganda, which might instill a defiant atmosphere of objection to any British influence, and mobilize many activists against them (Lloyd, 1933; Cromer, 1908b).

Cromer believed Islam held women in inferior positions, which was one of the reasons for Egypt's lack of progress. Their status was an obstacle to the realization of advancement in Egyptian thought and nature, and when the first efforts were made to advance women's education they were rejected by the general population. Most upper-class Egyptians were not only indifferent to the education of women, but were totally against it, and even when after great efforts, schools for girls were set up, parents sent the girls to schools under protest and got them out rather fast. In order to encourage girls' education, there was a need to accept a large number of girls with no tuition, and hence, most of the girls arrived from the poor families and left to get married, or because schooling for girls past the childhood years was not considered respectable (Cromer, 1908b; Tignor, 1966).

Mansfield stated the state of women was a barrier to Egypt becoming a cultured society, but it was expected for girls to be educated and for their state in society to improve (Mansfield, 1971). The character of Egyptian people was also an obstacle, when considering this unpromising human capital with whom the British had to work, who for centuries before the occupation, had relied on paralyzing intellect, and now the British had to work with people who gave little attention to the next day, to their future or to the future of those around them, 
whose life was only in the past and present, who accept fate and authority humbly, are over empathetic, and who have no initiative (Cromer, 1908b; Lloyd, 1933).

Cromer stated the new spirit of education was not because Egyptians sought education since they suddenly got the urge to gain knowledge, or became embarrassed about their ignorance, but rather could be attributed to the fact that in Egypt, a great part of the upper and middle class depended on government jobs, and parents suddenly realized that if their children did not go to school, they might not be able to make a living (Lloyd, 1933; Cromer, 1908b; Sladen, 1908).

Therefore, Cromer remained pessimistic regarding the Egyptians self-rule capabilities, though he maintained that if the Egyptians could ever learn to govern themselves, and if Egyptian policy could be made possible, the Egyptian problem would cease to be a problem in Europe and the British nation would be relieved of its enormous responsibility (Cromer, 1908b). Cromer claimed he did not believe any state could be rescued, nor did he believe any political problem could be solved via an enlightened government. Nevertheless, when observing the intensity of all the interests involved in Egypt, there are limits to the level of bad government which could be tolerated in the name of self-rule, there is no doubt that line would be crossed when Egypt would become autonomous. Cromer wondered what self-rule meant to Europeans. If it meant Egyptians were to be allowed to govern their state according to their own customs, then the mission of educating them towards self-rule was not only far from being easy, but should not have been done to begin with. He concluded that when Europeans refer to self-rule, they meant the Egyptians would be allowed to govern their own state only if they did it in the ways accepted by Europeans (Cromer, 1915). Personally, Cromer did not believe education could provide Egyptians full self-rule capabilities without changing their national customs and was certain it would take many years for Egyptians to govern based on civil principles (Cromer, 1915; Mansfield, 1971).

Language was an additional barrier. The French language which was highly influential in Egypt was an obstacle. The French responded verbally and aggressively to the British occupation and missed no opportunity to express their attitudes, and even took such steps as anti-British education they provided to their pupils. Cromer was certain if English were a free language which did not have to compete with the French, great educational projects would be implemented. Cromer, who had never learnt more than a few words in Arabic, believed the Egyptians would never get good education in their own language. Therefore, British teachers had problems teaching such subjects as history, geography and calculus to pupils whose knowledge of English was lacking. The same was true about the work of Egyptian and British administrators who had to work together without understanding each other's language (Lloyd, 1933; Mansfield, 1971; Newman, 1928).

Cromer set out against the criticism claiming his educational policy failed to 
create a breed of Egyptians who could not govern their country without foreign aid, for another reason which was time. He claimed the blame was not to be put on the British, and rather lies in the fact that two decades is a short time in a life of a nation. Material progress may be fast in some cases, but intellectual and moral progress develops slower and it takes more time to develop politicians' insights or even train skilled administrators than it takes to dig canals or build a railway. It was, he claimed, an absurd to believe a small number of Egyptians could be trained to such an extent that they could direct the complex political and administrative machines in the world (Cromer, 1908b; Mansfield, 1971). Cromer believed speed was not necessary for introducing reforms in Egypt, and that educational goals would only be achieved in the long term. On December $16^{\text {th }}, 1908$ he gave a speech after leaving Egypt, and said the Egyptian population was still deep in ignorance which would prevail until a new generation of Egyptians grew (Lloyd, 1933; Mansfield, 1971; Newman, 1928). An additional factor which increased the gaps between Egyptians and the British and interrupted their joint work for accepting Cromer's policy and implementing it were the differences between them. Cromer believed Egyptian thinking was inherently different from western thinking. He said the easterners speak and think in a manner that is opposite to that of the westerners, for no special reason. The gaps, he believed, consisted of religious views, and various ancient customs, international rivalries, interests and various aspirations. The Egyptians wee great in numbers, but were no more than zeros politically and administratively, claimed Cromer (Cromer, 1908b; Marlowe, 1970).

Furthermore, Cromer stated that one of the main obstacles to any reform in Egypt was the difficulty at that time, in finding the right agents who would execute and implement the reforms. Indeed, when young, inexperienced British officials were appointed to supervise the Egyptians, the latter considered it an intrusion and were upset. Nevertheless, the reasons for Cromer's decision to use the young British officials stemmed from his belief the Egyptian government relied on persons more than on laws (Al Sayyid, 1968; Colvin, 1906; Newman, 1928).

Finally, Cromer avoided taking effective steps also because of the policy of the royal government in England, which prevented any direct attempt to anchor such influence of the British culture, and due to this lack of stable policy, he said it was the duty of a diplomat in a foreign land was to try his best to implement his government's policy. His problem was, he claimed, the British government had never dictated any policy to him, which he could implement as he had never been guided (Cromer, 1908b; Lloyd, 1933; Al Sayyid, 1968).

\section{Local Responses}

Muhammad Abduh, one of the leaders of the national Egyptian movement supported changes in the Al-Azhar, seeking to turn it into a schooling system that would enlighten the Moslem world, not only in topics of religion, but also in secular issues, much like the universities in the west. He believed education had to 
be integrated with religious reforms. However, since the state of education in Egypt did not correspond to the needs of society (e.g. the number of good books in Arabic was limited, which had a direct influence on the educational level), more schools and universities had to be established in order to develop an educated Egyptian society (Sladen, 1908). He also criticized Cromer and maintained it was a mistake to expand only primary technical education, because the real need was for higher education, and that the state of education was rather shallow, which was, in his opinion, what the British intended to begin with, to prolong the situation whereby the Egyptians would not be enlightened enough to search for the real reasons for the British presence in Egypt (Tignor, 1966; Al Sayyid, 1968).

Ahmed Lutfi. Editor-in-chief of "al-Djarida" in 1906-1915 and spokesperson of the "el-Umma" ("The Nation") movement in 1907-1909, maintained education ought to groom the individual's personal independence as a personality trait, and to instill in the individual the desire to be a full, responsible partner in the life of society, as the power of a nation depends on its nature and social, economic and political reforms depend on the citizen's education as individuals. He believed education could help narrow gaps among citizens, and therefore, he supported education for women and believed the education system in Egypt had to consider all of the Egyptian population's characteristics. It had to be pragmatic and train citizens to active life in society (Al Sayyid, 1968; Vatikiotis, 1983).

Quasim Amin, a lawyer, wrote in 1899 an article about women's liberation and later published books on the topic, which were positively accepted by the Egyptian public. He encouraged more educational opportunities for women, so they would not be detached from society, and blamed women's slavery to men as the cause of Egypt's weakness, which had to be resolved by the citizens and their leaders. Thus, the problems, which he believed were closely linked to women's state, would disappear, and this was only possible if women were properly educated (Tignor, 1966; Al Sayyid, 1968).

In 1906 three political parties were established, which managed to govern Egypt's political arena until 1914: the people's party ("el-Umma"), the national party ("Watani"), and the constitutional reform party. All three parties had demands in the field of education: an advanced university, whose doors would be open to all of those seeking to study and acquire a scientific education. As such, the university would be a unique Egyptian educational center, from whence study delegations would be sent abroad. Second, they demanded the teaching language to be Arabic, and third, they demanded a radical change in educational policy to reach the goals (Alexander, 1911; Little, 1971). They criticized Cromer's educational policy of not allocating budgets to education and claimed as long as Dunlp was in charge of the finds, there would be no educated graduates in Egypt (Al Sayyid, 1968; Alexander, 1911).

Mustafa Kamil, founder of the national party ("Watani") and the editor of the nationalist daily newspaper, al-Liwa (the Banner) also criticized Cromer for not 
allowing Egyptians to realize their natural rights to proper education, and for the destruction of the Arabic language through his policy, due to the contempt he expressed for it, and replacing it by English as the teaching language in schools. Kamil called for the creation of a national Egyptian identity without which Egypt could not reach independence (Tignor, 1966; Al Sayyid, 1968; Sladen, 1908).

As the national movement expanded the study centers in the state, mainly the Law school, turned in to anti-British propaganda centers and gathering places for political protest and strikes. The students filled the coffee shops and engaged in political discussions, established political organizations, including a university graduates' club. It is interesting to note Sladen's observation claiming the nationalists did not wish for the majority of people to get an education, as they would lose control over them, and hence they preferred the people to remain ignorant, and thus, could influence them mechanically when they needed their votes in elections (Sladen, 1908).

A large group of literate people started leaving the rural areas, and included those sent abroad to acquire a high education, and those who did not pursue high education, flowed to the civil administrative jobs all over the land. When contact with western education and culture, educational possibilities were created, which attracted some of the youngsters in Egypt. Muhammad Abduh, knowing how government schools could not absorb the population wishing to learn and advance, he, together with some activists, established the Moslem Charity Society, whose goal was to set up schools for poor children in an attempt to provide national education by the power for private initiative. Those schools were meant to provide modern education while emphasizing Moslem educational values. In 1895, Abduh and Sliman were appointed by the government as its representatives in the Al-Azhar board of directors for academic and financial supervision, choosing texts, building a library, appointing staff and enforcing discipline (Tignor, 1966; Al Sayyid, 1968). In 1898, the university required the services of 13 professors from government schools, so they could teach calculus, geography and history (Newman, 1928).

\section{Conclusion}

Having examined Cromer's actions in the field of education, a few conclusions can be drawn: first, he regarded public education mostly as means of training public servants, and therefore, he ignored other educational goals, while at the same time he delayed the development of the locals' independent, liberal or democratic thinking. All of Cromer's actions corresponded to that line of thinking: budgets for education were insufficient, free education in Egyptian primary schools was abolished and the Egyptians also had to pay for high education.

The primary education did not get enough attention, which was contrary to Cromer's approach, and hence, a large part of the population did not receive any education. This was probably due to lack of suitable primary school curricula, to the introduction of English as the study language, which created communication 
difficulties between English teachers who knew no Arabic and Egyptian pupils who knew no English, instead of proliferating learning in Arabic while teaching the foundations of other languages, which harmed understanding and learning the different subjects. These characteristics and lack of attention also pertained to the education of women. Furthermore, the level of local teachers (who were heavily burdened) was low, as most of them did not receive advanced training. Those who did receive such training in England were taken to work in the ministry of Education rather than teach in the schools.

Cromer objected to establish a university. Instead of encouraging high education and the existing high education institutions, there was British intervention and a clear tendency to compete with the French language and teachers, and hence British people were appointed as school principals. Nevertheless, the wish to advance the medical school has to be noted. These efforts were expressed in bringing expert doctors to the school and sending graduates to internship in England.

Meanwhile, in the Ministry of Education, some changes were implemented, seeking to centralize the work by appointing British advisors, who did not speak Arabic, which created difficulties in the work with the Egyptians, holding examination bodies that did not always know their work, discipline and hard examinations which did not correspond to the harsh situation in the state.

Cromer's policy has to be examined in the context of British policy, which was ambiguous regarding education. Despite the belief in what was known as the British mission to save Egyptian society, it appears that imperialist approaches and interests did not go well with the teaching of liberal and human values. In this way, the British government gave Cromer a free hand to act for the recovery of Egypt and the organization of its affair. Priority was given to balancing the accounts, and hence, the domain of education was of secondary significance.

From 1906 Cromer changed his attitude to education. He transformed the Department of Education into a Ministry and appointed Zaghloul as the Minister of Education, allowing for Arabic to be reinstated as the official school language. Dunlop also advised the British to take Arabic lessons. An additional step which encouraged development and the proliferation of ideas regarding promoting education in Egypt, which also led to criticism of Cromer's policy, was the encouragement of free press. In that year there were great changes in England, expressed in the rise of a liberal government. Cromer wrote it was a widely supported government and the political atmosphere in England supported democratic ideas such as the need for the fast development of western institutions in eastern countries, and so, acknowledged the need for Egyptians to take an active, significant part in ruling their land.

An important outcome of Cormer's office in Egypt, was, in my opinion the growth of a significant generation in the development of Egypt, many of whom Cromer nurtured himself, those who were to lead objections to British occupation under the banner of a national movement, who led the change, such as Abdouh, Lutfi Al Sayyid, Zaghloul and Mustafa Kamil. It appears that British presence accelerated the development of the nationalist Egyptian movement due to 
the administrative experience they had gained with the help of the British. The implications of education described in this article including criticism of Cromer, were some of the factors, which aroused resistance to the foreign regime and torched the desire for self-rule, expressed in the formation of three parties, the proliferation of ideas and criticism in national papers, political propaganda of students and the significant development of Egyptian identity, and acknowledging the need for change in the education system and the wish to help the existing system by establishing charity societies for the development of schools, appointing supervisors for the Al-Azhar, the wish to develop science institutions like in the west, seeking to provide education to women and nurture the Arabic language. All these new thinking patterns were the outcome of contacts with the west and implementation of its culture.

The reasons for the criticism of Cromer and his education policy have to be understood. Nevertheless, the reality in which he operated has to be acknowledged. Externally, he faced lack of stability and Britain's failure to define educational goals, which gave him the freedom to use his personal judgment in light of the pressures exerted on him to lead the Egyptians to progress as a result of changes in British policy. Internally, he faced problems of lack of budgets, ignorance of the Pashas, communication problems because of the different languages, discrepancies due to different customs, and the Al-Azhar which constituted a barrier to advanced ideational development. In light of all this the question is how Croemr coped and operated?

It is our belief the answer lies in his high position in Egypt. He had the authority and was the true ruler of Egypt. Second, because of his personality-he was decisive and convinced his was the right way.

In sum, the issue of education in Egypt during Cromer's time has to be examined as a whole in the context of goals and their application, difficulties, implications and the local response. We believe there was a need to choose a different educational policy-creating an ongoing track from the primary school years to the high education institutions, which would impart good foundations in the different subjects, including mastery of Arabic as well as learning other languages; a track that would lead the selection of academic and vocational routes along the way. At the same time, it was important to develop unique domains such as natural science, medicine and agriculture, based on local needs, and considering the constraints of the social and educational patterns while seeking to construct a long-term educational program based on reached educational goals.

To conclude, though it is not our belief there was a regression in education during Cromer's time, progress was limited, or in other words, "Education Ltd." whose implications were reviewed here. Cromer was a reformer, but not a revolutionary in the short and long-term education in Egypt.

\section{References}

Al Sayyid, L. (1968). Egypt and Cromer. London: Murray. 
Alexander, J. (1911). The Truth about Egypt. London: Cassell.

Blunt, W. (1895). Secret History of the English Occupation of Egypt. London: Gereey International Publishers.

Cameron, D. (1898). Egypt in the Nineteenth Century. London: Smith Elder.

Colvin, A. (1906). The Making of Modern Egypt. London: Seeley Company.

Cromer, B. (1908a). Modern Egypt. V. 1. London: Macmillan.

Cromer, B. (1908b). Modern Egypt. V. 2. London: Macmillan.

Cromer, B. (1915). Abbas 2. London: Macmillan.

Elgood, G. (1928). The Transit of Egypt. New York: Russel and Russel.

Kadouri, E. (1969) Saad Zaghloul and the British. Tel Aviv: Keshet.

Lane, W. (1908). Manners and Customs of the Modern Egyptians. London: Aldine Press.

Little, T. (1971). Modern Egypt. London: Ernest Been Limited.

Lloyd, L. (1933). Egypt since Cromer. London: Macmillan,

Low, S. (1914). Egypt in Transition. New York: Macmillan.

Mansfield, P. (1971). The British in Egypt. London: Weidenfeld.

Marlowe, J. (1965). Anglo-Egyptian Relations 1800-1956. London: Frank Cass.

Marlowe, J. (1970). Cromer in Egypt. London: Thomas Nelson Printers.

Milner, A. (1904). England in Egypt. London: Edward Arnold.

Newman, P. (1928). Great Britain in Egypt. London: Cassell.

Sladen, D. (1908). Egypt and the English. London: Hurst and Blackett.

Tignor, R. (1966). Modernization and British Colonial Rule in Egypt 1882-1914. Princeton: Princeton University Press.

Vatikiotis, P. J. (1983). The History of Egypt from Muhammad Ali to Sadat. Jerusalem: Magnes. (In Hebrew)

Wallace, M. (1883). Egypt and the Egyptian Question. New York: Russell.

Young, G. (1927). Egypt. London: Ernest Benn Limited. 